\title{
NIA Region IV Employees Multi-Purpose Cooperative Marketing Strategy Implementation and Its Profitability: Basis for Marketing Plan
}

\author{
Michelle B. Concibido* \\ a michelleconcibido@gmail.com \\ ${ }^{a}$ Laguna College of Business and Arts (LCBA), Calamba City, Philippines \\ ${ }^{b}$ NIA Region IV Employees Multi-Purpose Cooperative (NEMCO), Philippines
}

\begin{abstract}
This study aimed to develop a marketing plan based on the level of implementation of the marketing strategy and profitability of NEMCO. The researcher employed the descriptive-correlational quantitative research and utilized a formal questionnaire to gather the data from the 331 NEMCO management and member respondents. The statistical treatment used to analyze the data were the weighted mean, ANOVA, and Pearson Product-Moment Correlation Coefficient. The result of the study shows that the marketing strategy in NEMCO was highly implemented as assessed by the management and members. The study revealed that there is a significant difference between the responses of the management and members on the level of implementation of marketing strategies and level of profitability in NEMCO. The NEMCO loan product matches the customers' needs and the Cooperative is strategically located and accessible by public transport making its location favorable for customers. Also, the organization uses an award system to encourage the members-owners to cooperate, while the organization's profitability was mainly from loan services. Thus, there was a significant relationship between the implementation of marketing strategy on the product, price, place, and promotion with NEMCO's profitability.
\end{abstract}

Keywords: cooperative, marketing strategy, profitability, marketing plan,4Ps.

\section{Introduction}

Cooperatives are based on the principles of cooperation and operate on internationally agreed standards and principles. They are private businesses that are owned and controlled by their members. (Copac, 2019). A cooperative can increase the financial profitability of its members through commercial operations. Typical transactions include the delivery by members of products for processing or marketing or the purchase of materials and supplies from cooperatives. Members' loyalty is important for maintaining a solid and successful job, which is the basis for a successful collaboration. Thus, strengthening member support should be a key element in the new cooperative strategy (Food and Agricultural Organization). 
Any organization needs to be distinct from its competitors. Businesses must establish their market position and be sensitive to customers' needs. Managers should focus on the marketing strategy and individual tools of the marketing mix because it represents a possibility to differentiate themselves from the competition. Thus, developing a timely marketing strategy is vital for any business. The strategy must focus on marketing while ensuring that products and services meet customer needs and developing long-term and profitable relationships with customers. This can be achieved by formulating a flexible strategy that is responsive to changes in customer perceptions and demand. To create an effective marketing strategy, product, price, place, and promotion need to be considered. These are the 4Ps of the marketing mix, controllable variables that will help to create effective marketing strategies (Cited by Nugroho and Iren 2017).

The NIA Region IV Employees Multi-Purpose Cooperative (NEMCO) was started in 1991 as a simple lending institution. Years passed, NEMCO also ventured into various services like credit, bank-like operation, special livelihood projects, small enterprise projects, and bidding on supplies and materials. Aside from low-interest rates, members enjoy an easy installment plan, provision for capital build-up, ready access for emergency needs, high-interest return on capital or fixed deposits, and patronage refund. NEMCO's objective is to provide alternative opportunities to its members through ready access to providential and productive loans, high yielding savings and time deposits, assured refund of excess payments, and the development of members' social responsibility and self-respect. The vision of the cooperative is to be sustainable and responsive to the development needs of a community by providing services based on the principle of equity and equality. However, providing economic benefit to its members in a consistent manner can be achieved through continuous business, members' patronage, and generating income. (NEMCO General Report, 2019).

Each organization aims to build a 4P's framework that will work on their customers' satisfaction and meet the company's profit goal. It is recommended that the company must strengthen the level of promotions in its activities and departments to increase sales. Khankaew et al. (2015), defined marketing strategy as a guideline or procedure to manage marketing activity that leads to success, enhances business performance, sustains competitive advantage, and maintains the business in the long term.

The study of Finoti et al. (2017) revealed that innovativeness does not influence organizational performance directly. Innovation is not enough to get better performance. Thus, the sequence of activities of the marketing strategy process can be a mechanism through which this happens. The indirect effect of innovation occurs through the improvement in marketing strategy, situational analysis, cross-functional integration, and quality of communication among others. Išoraite (2016) stated that in the marketing mix, certain actions and decisions are aimed to meet the company's goals and meet the customer's needs. According to the study of Nuseir and Madanat (2015), marketing mix positively affects the organization in the form of customer satisfaction, loyalty, and building a good reputation.

While Hys (2017) added that 4Ps should be given a new definition. Marketing strategies must be transformed for the need of the 21st-century generation that focuses on customer relationships on an individual basis. Decision-makers have to take into account changes in the structure, customer awareness, customer knowledge, and experience. Also, for marketing mix is to create significant added value in the future. Thus, personalized customer services create value.

In the perspectives of Garg et al. (2016), their arguments focus on customer convenience, distribution channels, and promotion. The organization needs to develop products with various options based on the requirements of customers. Enabling customers to make payments through various modes or installments can help them purchase conveniently. This may influence customers to identify a particular brand, patronize it repeatedly and promote it through word of mouth. Accordingly, Festa et al. (2016) mentioned that the marketing mix is considered to be one of the most important aspects of the marketing process. It plays an important role in satisfying customers' needs, meeting the demands of customers, and creating long-term, profitable relationships with them. 
According to Maverick (2020) in his article entitled Is Profitability or Growth More Important for a Business, a company's net profit is the revenue after all the expenses related to the manufacture, production, and selling of products are deducted. Profit is usually the main goal as this will add up to the company's capital. Bekmezci (2015), stated that profit is one of the most important factors that signify the business' success, shareholders' satisfaction, an attraction for investors, and the company's sustainability. Thus, one of the main goals of any company is to be sustainable in any competitive environment. Margaretha and Nina Supartika (2016), added that the primary goal of the company is to maximize its profitability. For management to further improve its performance, the focus must also be put on improving other factors that positively affect firms' profitability such as productivity.

The reviewed literature and studies above mentioned have indicated that the most reliable profitability basis of any organization is through the manifestation of a successful marketing mix. As stated by Nuseir and Madarat (2015), Hys (2017), Festa et al. (2016), along with other foreign authors, having a strategically planned marketing mix is one of the main lifelines of a business organization. Through the successful implementation of a marketing plan, business profitability is feasible. Every organization must have a marketing plan developed for its marketing operation. A marketing strategy should be tailored fit to the organization and its product and services making it possible to be delivered to its target niche.

Generally, the marketing strategy of a business serves as a springboard for the product and services to reach the market and score consumer patronage. However, it is either the make or fails of any business, marketing strategy as mentioned must be carefully planned and implemented. Moreover, in today's fast-paced business environment and changing consumer behavior, marketing strategy has become the highlight of most business organizations to become profitable whether they are into the traditional mode or in advanced delivery. This has a direct connection to the study of Maverik (2020), Beknezci (2015), Margareta \& Supartika (2016), and other investigators in the field.

While the marketing strategies of cooperatives and different businesses around the world have been investigated towards increasing profit, customer retention, and sustainable operation, the marketing strategy of local cooperatives in the region particularly for NEMCO have not been described in the literature. To address this gap in understanding of NEMCO's marketing strategies towards profitability and sustainability, this investigation was conducted on the Cooperative's members and management.

\section{Theoretical/Conceptual Framework}

This study was grounded to Kotler's 4Ps of marketing in the marketing operation of NEMCO. Likewise, to develop a basic marketing program towards the organization's profitability.

The researcher utilized the independent variable and dependent variable method to identify and determine the level of implementation of marketing strategy and the level of profitability in NEMCO as a basis for coming up with a paradigm as shown in the illustration below:

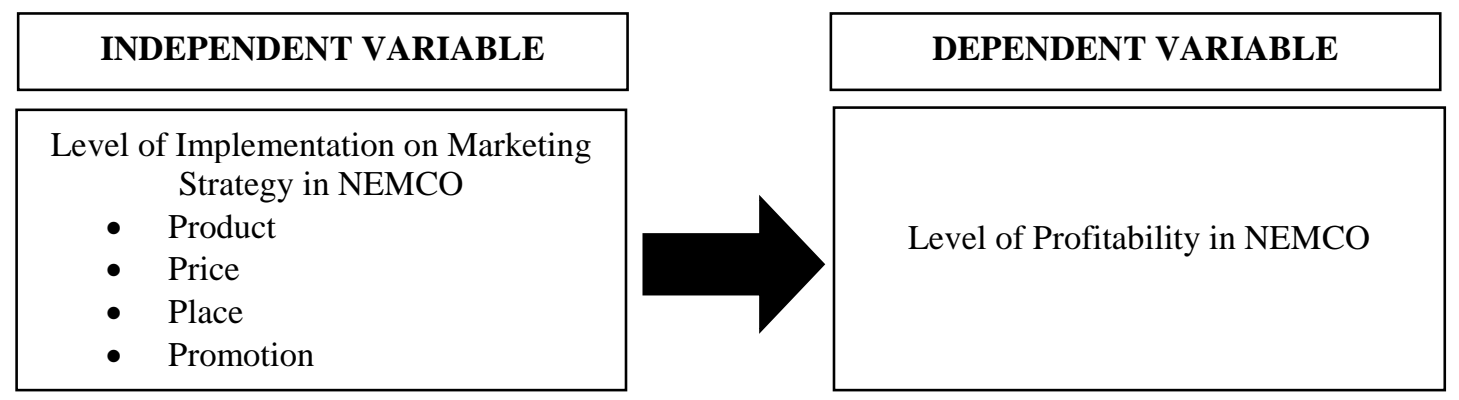

Figure 1. Research Paradigm 
The independent variables are the level of implementation of marketing strategy in terms of product, price, place, and promotion. The dependent variable is the NEMCO's level of profitability. The process of the study consists of problem identification, data collection, and organization.

\section{Hypotheses}

The following hypotheses were tested for their significance:

1. There is no significant difference in the assessments of the respondents on the level of NEMCO marketing strategy implementation.

2. There is no significant difference in the assessments of the respondents on the level of NEMCO profitability.

3. There is no significant relationship between the level of implementation of NEMCO's marketing strategy and its profitability.

\section{Scope and Delimitations}

The study has assessed the level of implementation of NEMCO's marketing strategy in terms of product, price, place, and promotion among its member-owners in Region IV. The study also included the assessment of the level of profitability. The respondents of the study were the employees and selected members of NEMCO.

\section{Methodology}

The researcher adopted a descriptive-correlational method using quantitative approaches in gathering information. The researcher used a modified survey questionnaire as the main data-gathering instrument for the study. Some of the portions on the test content used were from the thesis author Kidist Hunelegn (2019). The reliability of the tool was tested through the use of the Cronbach Alpha test which scored 0.95. For easy administration, scoring, and assessment of the survey questionnaire, the Likert scale was utilized. The four (4) point scale is ranging from four (4) being the highest and one (1) as the lowest. The respondents of the study were the members and management of NEMCO. The respondents were selected based on their availability at the time of survey or questionnaire distribution. The data gathering was conducted in a combined manner of online and manual procedure.

The data were analyzed using the weighted mean to determine the level of implementation of the marketing strategy and the level of profitability in NEMCO. To identify the difference between the assessments of the two groups of respondents, the Analysis of Variance (ANOVA) was used. To establish the relationship between the level of implementation on the marketing strategy and the level of profitability in NEMCO currently implemented, to interpret the total responses of all the respondents for every survey question the Pearson Product-Moment Correlation Coefficient was used. 


\section{Results and Discussions}

Table 1.1

Level of Implementation on Marketing Strategy in NEMCO as Assessed by Management and Members in terms of Product

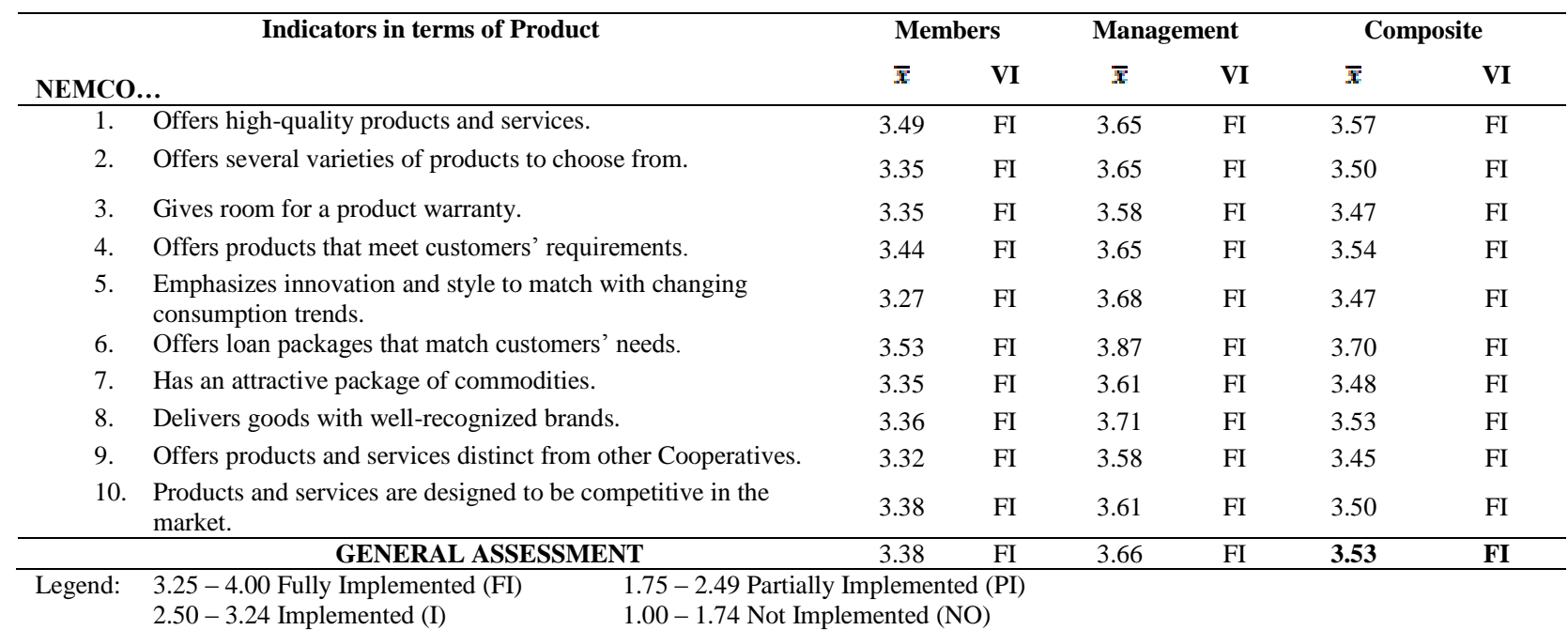

Table 1.1 showed the level of implementation of marketing strategy in NEMCO as assessed by management and members in terms of Product. The general assessment was $\mathbf{3 . 5 3}$ which was verbally interpreted as Fully Implemented. All indicators were verbally interpreted as Fully Implemented. The indicator "Offers loan packages that match customers' needs." has the highest computed composite mean of 3.70 while the indicator "Offers product and services distinct from other Cooperatives." has the least computed mean of 3.45 .

This implied that the NEMCO has fully implemented a marketing strategy in terms of Product as assessed by the members and management. It is evident that NEMCO offers loan packages that match customers' needs.

This is similar to what Verma and Singh (2017) defined as a product as a physical product or service to the consumer for which the consumer is willing to pay. Products are created by the company to fulfill customer needs and wants. Most companies are now into product innovation to match the customers' needs. Likewise, this is supported by the study of Ling and Mansori (2018) which reveals that companies should seek to build products based on the concepts of value innovation to satisfy the evolving and rapidly changing customers' needs. 
Table 1.2

Level of Implementation on Marketing Strategy in NEMCO as Assessed by Management and Members in terms of Price

\begin{tabular}{|c|c|c|c|c|c|c|c|}
\hline \multicolumn{2}{|r|}{ Indicators in terms of Price } & \multicolumn{2}{|c|}{ Members } & \multicolumn{2}{|c|}{ Management } & \multicolumn{2}{|c|}{ Composite } \\
\hline \multicolumn{2}{|c|}{ NEMCO... } & $\overline{\boldsymbol{x}}$ & VI & $\bar{x}$ & VI & $\overline{\boldsymbol{x}}$ & VI \\
\hline 1. & Product and services' price is affordable. & 3.41 & FI & 3.65 & FI & 3.53 & FI \\
\hline 2. & Pricing decisions allow discounts. & 3.40 & FI & 3.74 & FI & 3.57 & FI \\
\hline 3. & Pricing decisions allow installment payment. & 3.47 & FI & 3.90 & FI & 3.69 & FI \\
\hline 4. & Pricing decisions allow credit terms. & 3.42 & FI & 3.81 & FI & 3.61 & FI \\
\hline 5 . & Provides products and services with different price ranges. & 3.34 & FI & 3.71 & FI & 3.53 & FI \\
\hline 6. & Maintains the best everyday price for most products. & 3.38 & FI & 3.68 & FI & 3.53 & FI \\
\hline & $\begin{array}{l}\text { Uses pricing skills and systems to respond quickly to market } \\
\text { changes. }\end{array}$ & 3.30 & FI & 3.65 & FI & 3.47 & FI \\
\hline 8. & Product and services prices are determined by market surveys. & 3.23 & I & 3.52 & FI & 3.37 & FI \\
\hline 9. & Consistently provides the best value for money. & 3.34 & FI & 3.65 & FI & 3.49 & FI \\
\hline \multirow{2}{*}{\multicolumn{2}{|c|}{$\begin{array}{l}\text { GENERAL ASSESSMENT } \\
\text { GEN Pricing strategy }\end{array}$}} & 3.34 & FI & 3.58 & FI & 3.46 & FI \\
\hline & & 3.56 & FI & 3.69 & FI & 3.53 & FI \\
\hline Legend: & $\begin{array}{ll}3.25-4.00 \text { Fully Implemented (FI) } & 1.75-2.49 \text { Partia } \\
2.50-3.24 \text { Implemented (I) } & 1.00-1.74 \text { Not }\end{array}$ & $\begin{array}{l}\text { pleme } \\
\text { ented }\end{array}$ & & & & & \\
\hline
\end{tabular}

Table 1.2 showed the level of implementation of marketing strategy in NEMCO as assessed by management and members in terms of Price. The general assessment was $\mathbf{3 . 5 3}$ which was verbally interpreted as Fully Implemented. All indicators were verbally interpreted as Fully Implemented. The indicator "Pricing decisions allow installment payment." has the highest computed composite mean of 3.69 while the indicator "Product and services prices are determined by market surveys" has the least computed mean of 3.37.

The result shows that NEMCO has fully implemented its marketing strategy in terms of Price as assessed by the members and management. It is evident that NEMCO offers loan packages to its members that allow installment payments for customers.

In connection, according to De Toni et al. (2016), price is considered one of the most impacting elements in companies' performance. It was mentioned that it is paramount to maintain focus not only on competitors but also on pricing for current and potential customers. The price differentiation will create value for customers and provide the best pricing strategy that will leave an impact on the company's profitability and competitiveness. This price differentiation may apply to cash or installment basis of payment, it is the customers' preference to choose the price they can afford and are willing to pay. 
Table 1.3

Level of Implementation on Marketing Strategy in NEMCO as Assessed by Management and Members in terms of Place

\begin{tabular}{|c|c|c|c|c|c|c|}
\hline \multirow[t]{2}{*}{ Indicators in terms of Place } & \multicolumn{2}{|c|}{ Members } & \multicolumn{2}{|c|}{ Management } & \multicolumn{2}{|c|}{ Composite } \\
\hline & $\overline{\boldsymbol{x}}$ & VI & $\overline{\boldsymbol{x}}$ & VI & $\bar{x}$ & VI \\
\hline 1. Is convenient for public transport. & 3.65 & FI & 3.84 & FI & 3.75 & FI \\
\hline 2. Is near to most resident/working area. & 3.64 & FI & 3.81 & FI & 3.72 & FI \\
\hline 3. Is situated in an accessible place. & 3.63 & FI & 3.81 & FI & 3.72 & FI \\
\hline Covers various places in town. & 3.43 & FI & 3.55 & FI & 3.49 & FI \\
\hline Is situated in one of the safest places in the municipality. & 3.55 & FI & 3.61 & FI & 3.58 & FI \\
\hline 6. Is clearly described in the marketing materials. & 3.46 & FI & 3.61 & FI & 3.53 & FI \\
\hline Has easy-to-find distribution channels. & 3.38 & FI & 3.61 & FI & 3.49 & FI \\
\hline Is convenient for parking spaces. & 3.55 & FI & 3.77 & FI & 3.66 & FI \\
\hline 9. Is strategically located for facilitating logistics. & 3.36 & FI & 3.58 & FI & 3.47 & FI \\
\hline 10. Is best for holding inventory safety and maintenance. & 3.39 & FI & 3.65 & FI & 3.52 & FI \\
\hline GENERAL ASSESSMENT & 3.50 & FI & 3.68 & FI & 3.59 & FI \\
\hline
\end{tabular}

Table 1.3 showed the level of implementation of marketing strategy in NEMCO as assessed by management and members in terms of Place. The general assessment was $\mathbf{3 . 5 9}$ which was verbally interpreted as Fully Implemented. All indicators were verbally interpreted as Fully Implemented. The indicator "Is convenient for public transport" has the highest computed composite mean of 3.75 while the indicator "Is strategically located for facilitating logistics" has the least computed mean of 3.47.

The result shows that NEMCO has fully implemented its marketing strategy in terms of Place as assessed by the members and management. NEMCO's location is a convenient place accessible by public transport. As NEMCO's address is along the National Highway of Brgy. Labuin, Pila, Laguna, any form of transportation service is available on the site making it more convenient particularly to public commuters. Moreover, according to Ahmed and Rahnan (2015), a place or distribution channel is a way for the customers to have access to the products and services. This marketing mix element opens the doors for the rest of the elements of the marketing. 
Table 1.4

Level of Implementation on Marketing Strategy in NEMCO as Assessed by Management and Members in terms of Promotion

\begin{tabular}{|c|c|c|c|c|c|c|}
\hline Indicators in terms of Promotion & \multicolumn{2}{|c|}{ Members } & \multicolumn{2}{|c|}{ Management } & \multicolumn{2}{|c|}{ Composite } \\
\hline NEMCO/'s... & $\overline{\boldsymbol{x}}$ & VI & $\overline{\boldsymbol{x}}$ & VI & $\bar{x}$ & VI \\
\hline $\begin{array}{l}\text { 1. Considers sales promotion as an essential component of } \\
\text { promoting products and services. }\end{array}$ & 3.35 & FI & 3.61 & FI & 3.48 & FI \\
\hline $\begin{array}{l}\text { 2. Products and services are known based on the promotional } \\
\text { strategy. }\end{array}$ & 3.34 & FI & 3.55 & FI & 3.44 & FI \\
\hline 3. Applies advertising as one of the promotional strategies. & 3.29 & FI & 3.52 & FI & 3.44 & FI \\
\hline 4. Has sales promoters. & 3.20 & I & 3.29 & FI & 3.24 & I \\
\hline Applies personal selling as one of the promotional strategies & 3.18 & I & 3.39 & FI & 3.28 & FI \\
\hline 6. Considers the public understanding in promotion strategy. & 3.24 & I & 3.48 & FI & 3.36 & FI \\
\hline 7. Uses public relations in the promotion. & 3.32 & FI & 3.58 & FI & 3.45 & FI \\
\hline 8. Uses deadline incentive to encourage members & 3.36 & FI & 3.42 & FI & 3.39 & FI \\
\hline 9. Uses an award system to encourage members. & 3.41 & FI & 3.58 & FI & 3.50 & FI \\
\hline 10. Uses members' ideas and proposals. & 3.38 & FI & 3.55 & FI & 3.46 & FI \\
\hline $\begin{array}{c}\text { GENERAL ASSESSMENT } \\
\end{array}$ & 3.31 & FI & 3.50 & FI & 3.40 & FI \\
\hline $\begin{array}{ll}3.25-4.00 \text { Fully Implemented (FI) } & 1.75-2.49 \text { Parti } \\
2.50-3.24 \text { Implemented (I) } & 1.00-1.74 \text { Not }\end{array}$ & $\begin{array}{l}\text { pleme } \\
\text { ented }\end{array}$ & & & & & \\
\hline
\end{tabular}

As shown in Table 1.4, the general assessment on the level of implementation on marketing strategy in NEMCO as assessed by management and members in terms of Promotion was $\mathbf{3 . 4 0}$ and was verbally interpreted as Fully Implemented. The indicator "Uses an award system to encourage members" has the highest computed mean of 3.50 which was verbally interpreted as Fully Implemented while the indicator "Has sales promoters." has the least computed composite mean of 3.24 which was verbally interpreted as Implemented.

It can be concluded that NEMCO has fully implemented a marketing strategy in terms of Promotion as assessed by the members and management. It was also evident that NEMCO uses an award system to encourage the members.

As to Bradely (2020), promotion is the very concept of the marketing mix that is mostly associated with the word marketing itself. Promotion pertains to the elements of advertising, public relations, sales, and customer service. While Adefulu's (2015) findings reveal that a promotional strategy is a powerful tool to improve the performance of the organization. It is the promotion strategy that focuses to achieve the marketing objectives. Likewise, promotional strategy affected the market share and profitability of any organization at a significant level with the right promotional tools. 
Table 2

Test of Significant Difference between the Assessment of Members and Management on the Level of Implementation on Marketing Strategy in NEMCO in terms of Product, Price, Place, and Promotion

\begin{tabular}{|c|c|c|c|c|c|c|c|c|}
\hline & & $\begin{array}{l}\text { Sum of } \\
\text { squares }\end{array}$ & Df & $\begin{array}{l}\text { Mean } \\
\text { square }\end{array}$ & F Ratio & Sig. & Decision & Remarks \\
\hline \multirow[t]{3}{*}{ Product } & Between Groups & 2.110 & 1 & 2.110 & 11.163 & .001 & & \\
\hline & Within Groups & 62.199 & 329 & .189 & & & Reject $\mathrm{H}_{\mathrm{o}}$ & Significant \\
\hline & Total & 64.309 & 330 & & & & & \\
\hline \multirow[t]{3}{*}{ Price } & Between Groups & 2.933 & 1 & 2.933 & 14.462 & .000 & & \\
\hline & Within Groups & 66.726 & 329 & .203 & & & Reject $\mathrm{H}_{\mathrm{o}}$ & Significant \\
\hline & Total & 69.659 & 330 & & & & & \\
\hline \multirow[t]{3}{*}{ Place } & Between Groups & .906 & 1 & .906 & 5.705 & .017 & & \\
\hline & Within Groups & 52.226 & 329 & .159 & & & Reject $\mathrm{H}_{\mathrm{o}}$ & Significant \\
\hline & Total & 53.132 & 330 & & & & & \\
\hline \multirow[t]{3}{*}{ Promotion } & Between Groups & 1.030 & 1 & 1.030 & 4.395 & .037 & & \\
\hline & Within Groups & 77.081 & 329 & .234 & & & Reject $\mathrm{H}_{\mathrm{o}}$ & Significant \\
\hline & Total & 78.111 & 330 & & & & & \\
\hline
\end{tabular}

Level of significance 0.05

As shown in Table 2, the generated computed probability values of marketing strategies were .001 , $.000, .017$, and .037 respectively which were less than the level of significance of 0.05 ; thus, the null hypothesis is rejected. Therefore, there is a significant difference among the responses of the two groups of respondents on the level of implementation of marketing strategies in NEMCO.

This simply meant that the NEMCO management has a different perception compared to its members when it comes to the implementation of marketing strategies.

While Hys (2017) added that 4Ps should be given a new definition. Marketing strategies must be transformed for the need of the 21st-century generation that focuses on customer relationships on an individual basis. Decision-makers have to take into account changes in the structure, customer awareness, customer knowledge, and experience

As the marketing strategy of an organization can be viewed in two different perspectives, the management and the customers' side, Khankaew et al. (2015), mentioned that in all aspects, marketing strategy should serve as a guideline or procedure to manage marketing activity that leads to success, enhances business performance, sustains competitive advantage, and maintains the business in the long-term.

Moreover, Shankalia and Ramu (2018) cited that strong marketing strategies are important to the effectiveness of an organization. Marketing strategy involves deciding on the details for goal selection, choice of market, and customer target. It is best to find the best approach towards strategizing the marketing effort tailored fit to every organization. 
Table 3

Level of Profitability in NEMCO as Assessed by Management and Members

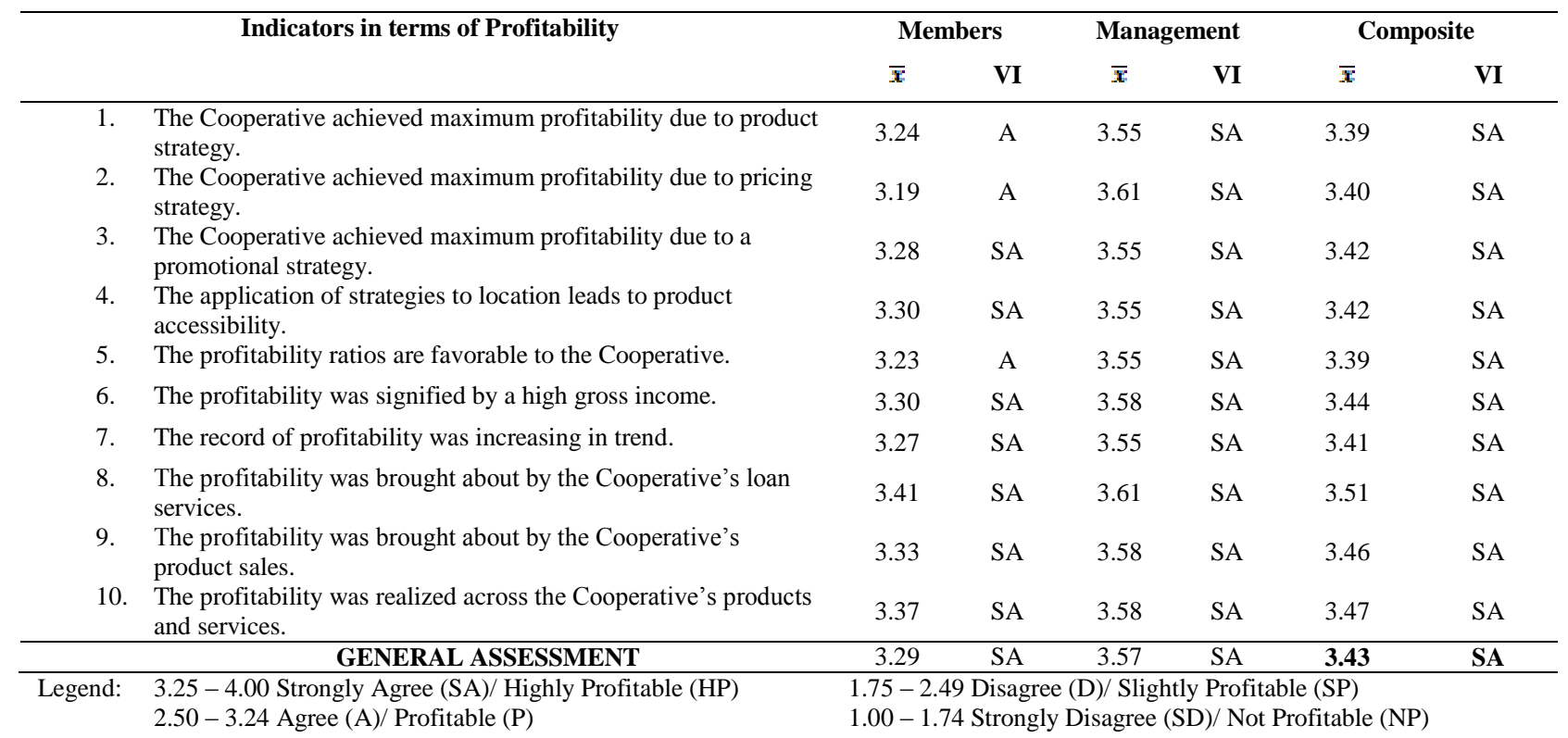

As shown in Table 3, the general assessment on the level of Profitability of NEMCO as assessed by management and members was $\mathbf{3 . 4 3}$ and was verbally interpreted as Highly Profitable. The indicator "The profitability was brought about by the Cooperative's loan services" has the highest computed mean of 3.51 which were verbally interpreted as Strongly Agree while the indicators "The Cooperative achieved maximum profitability due to product strategy" and "The profitability ratios are favorable to the Cooperative" have the least computed composite mean of 3.39 which was verbally interpreted as Strongly Agree.

It can be concluded that NEMCO is highly profitable as assessed by the members and the management. It was also evident that among NEMCO's products and services, profitability was brought about by the Cooperative's loan services.

According to Maverick (2020), a company's net profit is the revenue after all the expenses related to the manufacture, production, and selling of products are deducted. Profit is usually the main goal as this will add up to the company's capital. Without sufficient capital or the financial resources used to sustain and run a company, business failure is imminent. No business can survive for a significant amount of time without making a profit.

As to Margaretha and Nina Supartika (2016), the primary goal of the company is to maximize its profitability. For management to further improve its performance, the focus must also be put on improving other factors that positively affect firms' profitability. In particular, focus on products that bring more income to the organization is important while considering other factors like product innovation. Also, Bekmezci (2015) stated that profit is one of the most important factors that signify the business' success and one of the main goals of any company is to be sustainable in any competitive environment. For a company to be sustainable, developing, implementing, and maintaining a strategy to enhance its profitability performance is necessary. 
Table 4

Test of Significant Difference on the Responses of the Management and Members as to Profitability

\begin{tabular}{llrrrrrr}
\hline & & $\begin{array}{l}\text { Sum of } \\
\text { squares }\end{array}$ & Df & $\begin{array}{c}\text { Mean } \\
\text { square }\end{array}$ & F Ratio & Sig. & Decision \\
\hline Profitability & Between Groups & 2.181 & 1 & 2.181 & 11.363 & .001 & Reject $\mathrm{H}_{\mathrm{o}}$ \\
& Within Groups & 63.156 & 329 & .192 & & Significant \\
& Total & 65.338 & 330 & & & & \\
\hline
\end{tabular}

Level of significance 0.05

As shown in Table 4, the generated computed probability value of profitability was .001 which was less than the level of significance of 0.05 ; thus, the null hypothesis is rejected. Therefore, there is a significant difference among the responses of the two groups of respondents on the level of profitability in NEMCO.

This simply meant that the NEMCO management has different perceptions compared to its members when it comes to the level of profitability in NEMCO. Therefore, NEMCO management and members have different awareness on the generated profit of NEMCO. Though an annual Members' meeting is being conducted to report the results of operation, some Members may not be familiar with the actual data. On the other side, the Management is of course well aware of the actual figure of the bottom line being in the operational side of the business.

Nevertheless, both management and members have contributed shares in the Cooperative. Every member and management staff of the Cooperative is a shareholder. Consequently, Bekmezci (2015), stated that profit is one of the most important factors that signify the business' success. The bottom line is the shareholders' satisfaction, an attraction for investors, and the market for the company's sustainability.

Table 5

Test of Significant Relationship Between the Level of Implementation of Marketing Strategy and Profitability in NEMCO

\begin{tabular}{|c|c|c|c|c|c|}
\hline $\begin{array}{l}\text { Level of Implementation on } \\
\text { Marketing Strategy }\end{array}$ & Level of Profitability & r value & P value & Decision & Remarks \\
\hline Product & \multirow{4}{*}{ Profitability } & $.767 * *$ & .000 & Reject $\mathrm{H}_{\mathrm{o}}$ & Significant \\
\hline Price & & $.737 * *$ & .000 & Reject $\mathrm{H}_{\mathrm{o}}$ & Significant \\
\hline Place & & $.648 * *$ & .000 & Reject $\mathrm{H}_{\mathrm{o}}$ & Significant \\
\hline Promotion & & $.719 * *$ & .000 & Reject $\mathrm{H}_{\mathrm{o}}$ & Significant \\
\hline
\end{tabular}

As shown in Table 5, the $r$ values of all the variables were interpreted as moderately positive correlation as to the level of Implementation on Marketing Strategy and Level of Profitability, and the computed probability values were less than the level of significant $(\mathrm{P}<0.01)$; thus, the null hypothesis is rejected. The result showed that there is a significant relationship between the dependent and independent variables.

It can be concluded that the implementation of marketing strategy particularly on product, price, place, and promotion has a significant relationship with profitability level in NEMCO.

Correspondingly, Nuseir and Madanat's (2015) study on marketing mix mentioned that it positively affects the organization in the form of customer satisfaction, loyalty, and building a good reputation. The 4Ps marketing mix focuses on customers' intentions that boost customer satisfaction that later turns into loyalty. Customer satisfaction and royalty can be translated to profitability. While Hys (2017) added that 4Ps should be given a new definition. Marketing strategies must be transformed for the needs of the 21st-century generation that focuses on customer relationships and creating significant added value in the future for sustaining profitability. 


\section{Recommendation}

Sustaining the marketing strategy of NEMCO will provide continuous operation and profitability of the organization. Enhancing the marketing strategy for product design by conducting a product research/survey to have a basis for innovating new products or for enhancing an existing profitable product at hand is a good strategy. Likewise, offering competitive prices of products and services by applying riskbased pricing applicable to every product and service may improve profit trends. For increasing customer volume, NEMCO may expand its service areas to unventured locations in the region by marketing clients within the scope of operation where the number of customers is at a minimum. For catching up with technological advancement and consumer-friendly operation, NEMCO may enhance its promotional platform by marketing products and services through streaming an operational NEMCO Website. Thus, establishing and implementing a formal marketing plan to enhance the marketing strategy and for sustainable operation and increasing profit is a feasible approach.

Below is the proposed marketing program of NEMCO for implementation in the next two years of operation. This particularly detailed the marketing strategies to be implemented towards achieving greater market share and maintaining client relationships. The proposed program includes the budget proposal and responsible people to accomplish the marketing plan of the organization based on the 4Ps marketing assessment. 
Appendix A

The Proposed Marketing Program

\begin{tabular}{|c|c|c|c|c|c|c|}
\hline $\begin{array}{l}\text { AREAS OF } \\
\text { CONCERN }\end{array}$ & OBJECTIVES & $\begin{array}{l}\text { STRATEGIES/ } \\
\text { ACTIVITIES }\end{array}$ & $\begin{array}{l}\text { TIME } \\
\text { FRAME }\end{array}$ & $\begin{array}{l}\text { PERSON } \\
\text { INVOLVED }\end{array}$ & BUDGET & $\begin{array}{l}\text { SUCCESS } \\
\text { INDICATOR }\end{array}$ \\
\hline Product & $\begin{array}{l}\text { To increase } \\
\text { profitability } \\
\text { For Product } \\
\text { Innovation }\end{array}$ & 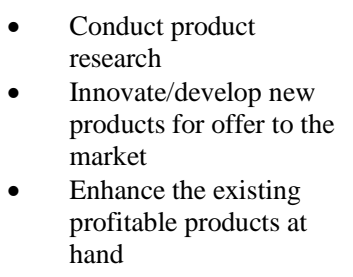 & Year 1 & Management & $\begin{array}{l}\mathrm{P} 10,000.00 \\
\text { (for research) }\end{array}$ & $\begin{array}{l}1-2 \\
\text { new/enhanced } \\
\text { products for } \\
\text { offer to the } \\
\text { market }\end{array}$ \\
\hline Price & $\begin{array}{l}\text { To increase } \\
\text { profitability } \\
\text { To maintain price } \\
\text { competitiveness }\end{array}$ & $\begin{array}{l}\text { - } \\
\text { - } \quad \text { researchduct market } \\
\text { Apply risk-based } \\
\text { pricing }\end{array}$ & Year 1 & Management & $\begin{array}{l}\mathrm{P} 10,000.00 \\
\text { (for research) }\end{array}$ & $\begin{array}{l}10 \% \text { increase in } \\
\text { net income } \\
10 \% \text { increase in } \\
\text { customer volume } \\
\text { (end of financial } \\
\text { year upon } \\
\text { implementation) }\end{array}$ \\
\hline Place & $\begin{array}{l}\text { To increase } \\
\text { profitability } \\
\text { For the } \\
\text { expansion of } \\
\text { service areas }\end{array}$ & $\begin{array}{l}\text { Develop new market } \\
\text { niche for products and } \\
\text { services } \\
\text { Position the product on } \\
\text { websites and social } \\
\text { media to create } \\
\text { awareness }\end{array}$ & Year 1-2 & Management & & $\begin{array}{l}5 \% \text { visibility of } \\
\text { clients from } \\
\text { unventured } \\
\text { areas/location }\end{array}$ \\
\hline Promotion & $\begin{array}{l}\text { To increase } \\
\text { profitability } \\
\text { To enhance } \\
\text { Marketing } \\
\text { Channel }\end{array}$ & $\begin{array}{l}\text { Develop a website and } \\
\text { social media platform } \\
\text { to enhance marketing } \\
\text { and business operation }\end{array}$ & Year 1-2 & Management & $\mathrm{P} 25,000.00$ & $\begin{array}{l}\text { Operational } \\
\text { NEMCO } \\
\text { Website } \\
10 \% \text { increase in } \\
\text { income } \\
10 \% \text { increase in } \\
\text { customer volume }\end{array}$ \\
\hline
\end{tabular}

\section{References}

Adefulu, A,D (2015). Promotional Strategy Impacts on Organizational Market Share and Profitability.Acta Universitatis Danubius. Economica, Vol 11, No 6 2015.http://journals.univ-danubius.ro/index.php/oeconomica/article/view/3032/3023

Ahmed, S \& Rahman, H (2015). The Effects of Marketing Mix on Consumer Satisfaction: A Literature Review from Islamic Perspectives. Türkiye İslam İktisadı Dergisi, Cilt 2, Sayı 1, Şubat 2015, ss. 17-30 Turkish Journal of Islamic Economics, Vol. 2, No. 1, February 2015, pp. 17-30

Bekmezci, M. (2015). Companies' profitable way of fulfilling duties towards humanity and environment by sustainable innovation. Procedia - Social and Behavioral Sciences 181, 228 - 240. https://www.researchgate.net/publication/277026717

Bradley, J. (2020).How to Study the Importance of a Marketing Mix. Retrieved from https://smallbusiness.chron.com/study-importancemarketing-mix-71890.html 
De Toni, D., Milan G.S, Saciloto, E.B \& Larentis, F. (2017) Pricing Strategies, and Levels and their Impact on Corporate Profitability/ Rev. Adm. (São Paulo) vol.52 no.2. https://doi.org/10.1016/j.rausp.2016.12.004 /

Digital Library (2019). Cooperatives for Decent Work. International Day of Cooperatives Retrieved from https://www.copac.coop/about cooperatives

Festa, G., Cuomo, M. T., Metallo, G., \& Festa, A (2016). The (r) Evolution of Wine Marketing Mix: From the 4Ps to the 4Es. Journal of Business Research, 69, 1550-1555.

Finoti, L, Didonet, S R, Toaldo, A \& Martins, T. (2017). The Role of the Marketing Strategy Process in the Innovativeness-Performance Relationship of SMEs. Marketing Intelligence \& Planning; Bradford Vol. 35, Iss. 3, (2017): 298-315. DOI:10.1108/MIP-01-20160005

Food and Agricultural Organization (FAO). Retrieved from https//www.fao.org

Garg, S A; Singh, H. \& De, K K (2016). Direct and Indirect Effects of Marketing Mix Elements on Satisfaction. Academy of Marketing Studies Journal; Arden Vol. 20, Iss. 1, (2016): 53-65.

Hys, K. (2017). Mechanisms Stimulating Actions Customer - Decision Maker on the Market: Marketing Mix Instruments. DIEM : Dubrovnik International Economic Meeting; Dubrovnik Vol. 3, Iss. 1, : 566-576. Dubrovnik: University of Dubrovnik

Išoraitè, M (2016). Marketing Mix Theoretical Aspects. International Journal of Research - Granthaalayah, Vol. 4, No. 6 (2016): 25-37

Khankaew, C., Ussahawanitichakit, P. \& Raksong, S. (2015). A Conceptual Framework of Alternative Marketing Strategy and Marketing Outcomes. Allied Academies International Conference. Academy of Marketing Studies. Proceedings; Arden Vol. 20, Iss. 2, (2015): $1-16$.

Langat, N. (2016).Influence of Product, Price, Promotion and Place on Enterprise Project Performance: A Case of Safaricom Enterprise Project, Uasin Gishu County, Kenya. URI http://hdl.handle.net/11295/97861

Ling, C.H \& Shaheen Mansori, S (2018).The Effects of Product Quality on Customer Satisfaction and Loyalty: Evidence from Malaysian Engineering Industry. International Journal of Industrial Marketing 3(1):20-35 DOI: 10.5296/ijim.v3i1.13959/

Manthei, L. ( 2017) The Four Ps of Marketing: Why the Marketing Mix Is Still Relevant. Retrieved from https://emarsys.com/learn/blog/4-ps-of-marketing-importance/

Margaretha, F. \& Supartika, N. (2016). Factors Affecting Profitability of Small Medium Enterprises (SMEs) Firm. Journal of Economics, Business and Management, Vol. 4, No. 2, February 2016. Retrieved from http://www.joebm.com/vol4/379-ET10002.pdf

Masicat, J.D (2014). Batangas Heavy Fabrication Yard Multi-Purpose Cooperative: Basis for Business Operation. Asia Pacific Journal of Multidisciplinary Research Vol 2. No.4,2014

Maverick, J. B (2020).Is Profitability or Growth More Important for a Business?. Retrieved from https://www.investopedia.com/ask/answers/020415/what-more-important-business-profitability-or-growth.asp

NEMCO ( 2019). General Assembly Report

Nugroho, A.R \& Irena, A (2017). The Impact of Marketing Mix, Consumer's Characteristics, and Psychological Factors to Consumer's Purchase Intention on Brand "W" in Surabaya. iBuss Management Vol. 5, No. 1, (2017) 55-69. Retrieved from https://media.neliti.com/media/publications/182962-EN-the-impact-of-marketing-mix-consumers-ch.pdf

Nuseir, M.T \& Madanat, H. (2015). 4Ps: A Strategy to Secure Customers' Loyalty via Customer Satisfaction. International Journal of Marketing Studies; Vol. 7, No. 4; 2015 ISSN 1918-719X E-ISSN 1918-7203 Published by Canadian Center of Science and Education. URL: http://dx.doi.org/10.5539/ijms.v7n4p78

Paurova, V \& Nadanyiova, M (2020). Marketing mix as part of Marketing Strategy used in the Service Industries. Economic and Social Development: Book of Proceedings; Varazdin Vol. 0, : 649-657. Varazdin: Varazdin Development and Entrepreneurship Agency (VADEA)

Pourdehghan, A. (2015) . The Impact of Marketing Mix Elements on Brand Loyalty: A Case Study of Mobile Phone Industry. Marketing and Branding Research. DOI: 10.33844/mbr.2015.60184

Republic Act 9520 (2009). Cooperative Development Authority. Retrieved from https://cda.gov.ph > philippine-cooperative-code-of2008

Sancheti, P (2019). The cooperative movement in the Philippines. Retrieved from https://medium.com/impact-insurance/the-cooperativemovement-in-the-philippines

Shafi, S.I (2018). Managing Marketing Strategies \& Brand Equity. Retrieved from https://www.morebooks.de/books/us/published_by/lap-lambert-academic-publishing

Shankalia, U \& Ramu, M (2018). A Study on Marketing Strategy of Apple Products 1M /International Journal of Pure and Applied Mathematics Volume 119 No. 17 2018, 551-559 ISSN: 1314-3395 (on-line version) url: http://www.acadpubl.eu/hub/

Sudaria*, S.A, Tarofderb,A.K, Khatibia, A \& Thama,J (2019).Measuring the Critical Effect of Marketing Mix on Customer Loyalty through Customer Satisfaction in Food and Beverage Products. Management Science Letters 9(9):1385-1396. DOI: 10.5267/j.msl.2019.5.012

Thabit, H \& Raewf, M.B (2018) The Evaluation of Marketing Mix Elements: A Case Study. International Journal of Social Sciences \& Educational Studies ISSN 2520-0968 (Online), ISSN 2409-1294 (Print), March 2018, Vol.4, No.4. doi: 10.23918/ijsses.v4i4p100

Verma, Y., \& Singh, M. R. (2017). Marketing Mix, Customer Satisfaction and Loyalty: An Empirical Study of Telecom Sector in Bhutan. Indian Journal of Commerce and Management.. 54. 